\title{
Global benchmarking for monitoring environmental, economic, and social performance for metallurgical production enterprises
}

\author{
Valentyna Lavrenenko, ${ }^{1, *}$, Hanna Yanhol'2, and Bohdan Tishkov ${ }^{3}$ \\ ${ }^{1}$ Kyiv National Economic University named after V. Hetman, Business Economics and Entrepreneurship Department, 54/1 Peremogy Ave., \\ Kyiv, 03057, Ukraine \\ ${ }^{2}$ State Budgetary Institution of Health Care of Sevastopol "Medical Information and Analytical Center”, 6 Pravdy Str., Sevastopol, 299014, \\ Crimea \\ ${ }^{3}$ Kyiv National Economic University named after V. Hetman, Economics Information Systems Department, 54/1 Peremogy Ave., Kyiv, 03057, \\ Ukraine
}

\begin{abstract}
The development of the ideology of sustainable development stimulated the emergence of companies' Performance Management Systems with an emphasis on the environmental aspects of their activities. Benchmarking, as a modern management tool, is often used for competitive analysis and setting development goals. This study's scientific problem is to assess the feasibility of applying benchmarking studies to assess the global industry's environmental aspects. The purpose of the study is to identify the prerequisites for using benchmarking to improve environmental performance, as well as to identify best practices among world-leading companies. For benchmarking, a logical information model is proposed in the study. On its basis, eight world leaders were selected, trends in the industry's development were analysed, and reference values of environmental indicators were established. For environmental performance assessment, it is proposed to use such indicators as greenhouse gas emissions, energy consumption, material efficiency, environmental management systems. Comparative benchmarking analysis of world leaders and 16 largest Ukrainian companies allowed determining the reserves for increasing environmental performance. The directions for increasing environmental performance are Investment in resource-saving technologies, production of higher value-added products, investments in energy-saving and new technologies, improvement of management systems, and certification. These ideas are complemented by recommendations for improving environmental performance, based on the Circular Economy Concept's philosophy and Industry 4.0. The study's practical significance is that Ukrainian companies can use their results to achieve higher environmental and economic outcomes.
\end{abstract}

\section{Introduction}

\subsection{Research question}

Metallurgy is a factor in the success of national economies and the basis of global sustainable development, as well as a driver of related industries - shipbuilding, aviation, transport and heavy engineering, defence industry, energy, construction. In addition, the metallurgical industry is a source of environmental problems, as it produces harmful emissions into the atmosphere, wastewater and generates waste that pollutes the soil in the surrounding areas. Due to the extraction of ferrous and non-ferrous metals, there is a subsequent degradation and land quality change. The metallurgical industry is also responsible for thermal pollution.

The scale of world trade, the transnational nature of leading manufacturers, and their predominant export orientation confirms the industry's global nature.

According to the results of 2019, Ukraine is one of the leading producers of metallurgical products in the world. It ranks 13th (in $2016-7$ th) among the top exporters of metal products in terms of total exports (13.5 million tons) and fourth after China (60.9), Japan (31.2), and Russia (24.9) in terms of net exports (the difference between the number of exported and imported products of the industry). In 2019, the products of the metallurgical industry amounted to $20.5 \%$ (2nd place) in the total structure of exports from Ukraine.

The peculiarities of the development of the metallurgical industry in Ukraine are excessive capacities and technological backwardness, dependence on foreign trade, as well as a high level of openness of the industry (the coefficient of openness of foreign trade in Ukraine is 5.2 versus 0.7 in China, 1.8 - in the Russian Federation and 2.8 - in the USA). In addition, Ukrainian metallurgy produces a relatively small share of finished products with a large production of semi-finished products. As a result, Ukrainian products are not competitive enough. The industry is also characterized by low use of secondary raw materials and high capital and energy consumption. The industry is highly monopolized, led by vertically integrated holdings. Six manufacturers account for $84 \%$ of the industry's sales. Significant differences in productivity levels are observed between the largest holdings and other domestic producers.

\footnotetext{
Corresponding author: vlave@ukr.net
} 
The last decade has been characterized by the spread of the ideology of sustainable development with the simultaneous digitalization of the economy. This has led to the emergence of new models and indicators for companies' Performance Management Systems (PMS) and has identified critical areas for improving their business models. As part of sustainable development, PMS has been dubbed "Sustainable and Resource Efficient Business Performance Measurement Systems" (SuRE BPMS). Enterprise performance and the methods used to measure and manage it are studied in theories of management, organization, and information systems (in particular, in business process management or BPM) [1]. Performance management is a multidisciplinary topic and assumes the existence of differentiated approaches to implementing tools to ensure it. One such tool, which is not widespread enough to solve environmental problems, is benchmarking.

The research question in this paper is to analyze the possibilities of improving performance based on global benchmarking and attention to issues of sustainable development. The use of benchmarking for sustainable development will allow metallurgical companies to calculate the quantitative parameters of the changes needed to increase competitiveness, including the environmental vector.

\subsection{Previous researches}

The basis of modern Sure BPMS systems is the concept of global effectiveness of sustainable development "Triple Bottom Line" [2], which is used to assess sustainable development strategies based on a set of economic, social, and environmental indicators (Figure 1). This concept maintains a balance between the three goals.

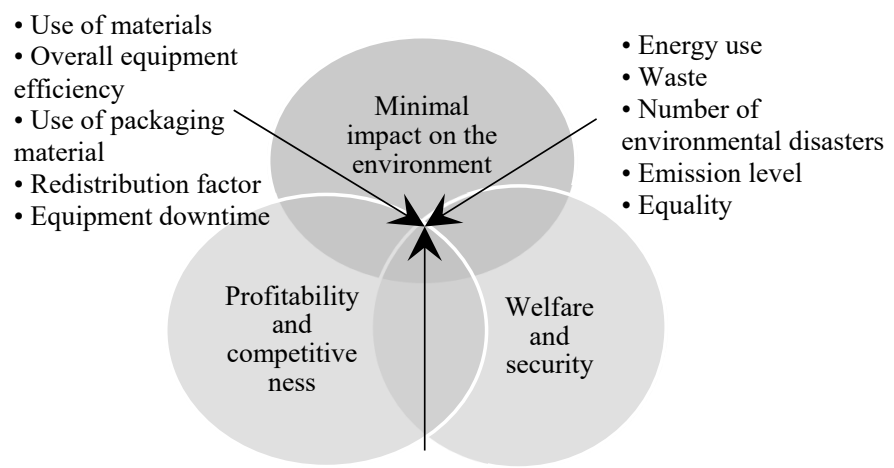

$$
\begin{gathered}
\text { - Employee satisfaction level } \\
\text { - Number of accidents } \\
\text { - Salary level } \\
\text { - Staff turnover }
\end{gathered}
$$

Fig. 1. The concept of the global performance of sustainable development "Triple Bottom Line" [2].

First, maximizing economic performance. This goal can be measured by traditional financial criteria (revenue, profitability, cash flow, economic value-added, market value-added, etc.).
Second, maximizing social performance, which requires taking into account the interests of all stakeholders. Third, the increase in environmental performance involves activities that do not create harmful effects on the environment [3].

According to the concept, a sustainable corporation strives for low environmental impact, cares about staff and society as a whole while remaining competitive. The basis for sustainable production is to create more value while using fewer resources. Resource efficiency is a consequence of every production operation. The resources spent do not add value to the client and represent costs for the enterprise and society. The critical challenge is to link improvements in resilience at the operational level to financial performance and stability at the corporate strategic level.

Central to today's process-oriented models developed in the BPM concept is the Measurement and Performance Management Lifecycle Model proposed by Bourne \& Bourne in 2011, which consisted of four phases: design, implementation, use, and revision. This model was supplemented by Landström et al. [4] in 2018, the fifth stage - the cycle of double learning. Central to the model is the choice of adequate performance indicators for specific prospects for implementing the corporate strategy.

The development of the ideas of the "Triple Bottom Line" and the Bourne \& Bourne Life Cycle Model is manifested in the System of Measuring Enterprise Performance Based on Sustainable Development by Almström et al. [5]. The authors note that performance measurement systems' use and improvement are closely linked to management systems, such as environmental protection, quality, occupational health and safety, and operational development programs. The integration of management systems and operational development programs involves the development and maintenance of appropriate PMS. In practice, management systems and operational development programs are not fully integrated and contain different key performance indicators. Success factors for operational development from the authors of the model's point of view can be the participation of management, training, education, empowerment of workers, and coordination of long-term strategy.

Thus, modern SURE models reflect PMS development's last stage, forming a modern philosophy of integrated performance measurement concept, which combines BSC elements, process-oriented life cycle models, and business excellence models, and subordinating PMS to a single system of strategic management. According to the authors, performance indicators should provide the right feedback for strategic decisions. At the heart of the benchmarking methodology, as you know, is the process of comparing the potential of a particular object of analysis (enterprise, industry, etc.) with the potential of competitors. Therefore, the use of benchmarking, in our opinion, can be considered an instrumental implementation of modern models of performance management. 


\subsection{The scientific problem}

The scientific problem is the possibility of using benchmarking studies of the global industry to improve the performance of national manufacturers based on the philosophy of sustainable development and the use of relevant models of Sustainable and Resource Efficient Business Performance Measurement Systems. The article's hypothesis has both a theoretical and an applied basis concerning the practicality of using benchmarking results and the technology of using its consequences in the global market. The purpose of this study is to identify the prerequisites for using benchmarking to influence the environmental performance of market participants, identify best practices and their carriers among worldleading companies and test the proposed toolkit for Ukrainian companies. The research object is the environmental, social, and economic performance of companies in the metallurgical sector in the world and Ukraine.

\subsection{The research methodology}

The research is based on the data on metallurgy from global and national statistics of Ukraine, as well as data from top global and Ukrainian producers of metallurgical products, collected directly from companies and processed by statistical methods.

The analysis of global trends covers 1980-2019, with details for the period 2007-2017.

To monitor environmental, economic, and social performance for benchmarking the metallurgical industry, we have selected eight largest world companies representing the TOP countries of the industry sample of comparisons and key areas: 1) Production of iron, steel, and ferroalloys: ArcelorMittal (Luxembourg), Nucor (USA), POSCO (South Korea), China Baowu Grou (China), Nippon Steel \& Sumitomo Metal Corporation (NSSMC) (Japan), OJSC Novolipetsk Metallurgical Plant (NLMK) (RF) 2) Production of light metal packaging: Crown Holdings, Inc. (USA) 3) Manufacturing of metal structures and products: Lindab group., Inc. (EU).

To test the use of benchmarking for national manufacturers' performance, we formed a sample of 16 largest Ukrainian companies, which provided $88 \%$ of the total sales of the metallurgical industry of Ukraine. The first six (Metinvest Holding, ArcelorMittal Ukraine, Privat Group, EastOne Group (Interpipe), Donbass Industrial Union (ISD), and DCH-Evraz) accounted for $84 \%$ of industry-wide sales. The 16 largest companies accumulate $80 \%$ of assets and $56.6 \%$ of employees in the industry.

The sample proportion fully corresponds to the scale of enterprises' activities, both globally and nationally.

The methodology's scientific novelty is as follows: Authors propose identifying three groups of benchmarking parameters, which reflect environmental, social, and economic performance. To assess the environmental performance, the authors of this article proposed to use such indicators as Greenhouse gas emissions, Energy consumption, Material efficiency,
Environmental management systems.

An analysis of the environmental aspects of the metallurgical sector showed that Environmental requirements should be viewed as an incentive for innovation and as a source of competitive advantage. Environmental requirements are also a push to eliminate structural crisis phenomena.

For benchmarking, the article proposes a logical information model, the main elements of which are the selection of a narrow range of players in the metallurgical market as carriers of "best practices", analysis of trends in the global development of the industry, setting benchmark targets, and their comparison with the indicators of Ukrainian companies.

\subsection{The current research structure}

This study consists of the following parts:

- first of all, a theoretical basis is presented, based on the study of modern models of performance management in the context of sustainable development; on this basis, a logical-informational model of benchmarking and a group of indicators for assessing environmental, economic, and social performance are proposed;

- secondly, the prerequisites for the use of benchmarking for the analysis of the metallurgical industry were investigated; trends in the development of metallurgy at the global and national levels were revealed;

- thirdly, the results of the analysis of performance indicators for two groups of companies - global leaders and Ukrainian manufacturers are presented, and recommendations for improving environmental performance based on the results of global benchmarking are proposed;

- further, the ideas of improving environmental performance are considered through the prism of the Concepts of the circular economy and Industry 4.0.

The study's practical significance lies in the fact that its results can be used to achieve higher environmental and economic results by Ukrainian companies and, as a result, to create and maintain competitive advantages in the world market through the use of benchmarking in management practice.

\section{Main theoretical assumptions of the research}

\subsection{Environmental, economic, and social performance under the ideology of sustainable development}

Following the doctrine of sustainable development, we propose identifying three groups of parameters for benchmarking, which reflect the environmental, social, and economic performance, and determine the sociallyoriented strategic management on the corporate social responsibility principles. According to the authors' approach, this approach to community-based management is an extended modification of the "Eight 
Global Economic, Social and Environmental Indicators" of WSA Sustainability [6].

Indicators of environmental performance are given in table 1 .

Table 1. Indicators for assessing environmental performance (based on the benchmarking of global industry leaders).

\begin{tabular}{|l|l|}
\hline \multicolumn{1}{|c|}{ Indicator } & \multicolumn{1}{c|}{ Calculation } \\
\hline $\begin{array}{l}\text { Greenhouse gas } \\
\text { emissions }\end{array}$ & tons of $\mathrm{CO}_{2}$ per ton of steel \\
\hline Energy consumption & GJ per ton of steel \\
\hline Material efficiency & $\begin{array}{l}\text { The ratio of the mass of the obtained } \\
\text { scrap to the mass of residues and } \\
\text { production waste, \% }\end{array}$ \\
\hline $\begin{array}{l}\text { Environmental } \\
\text { management systems }\end{array}$ & $\begin{array}{l}\text { Share of personnel and contractors } \\
\text { working at certified production } \\
\text { facilities, \% }\end{array}$ \\
\hline
\end{tabular}

The greenhouse gas emissions $\left(\mathrm{CO}_{2} / \mathrm{t}\right)$ show tons of $\mathrm{CO}_{2}$ emissions normalized against production (tons of manufactured metallurgical products in crude steel equivalent). The calculation is based on the specific energy trajectory and intensity of $\mathrm{CO}_{2}$ emissions for the main production routes. Reducing greenhouse gas emissions in steel production needs to be addressed globally. Reducing $\mathrm{CO}_{2}$ emissions requires breakthrough technologies. Metal products play an essential role in a low-carbon economy due to their long life cycle, $100 \%$ recycling, and innovative qualities.

Energy intensity, GJ per ton of steel, shows the energy consumed, normalized to production (equivalent to a ton of crude steel), and reflects energy-saving policies' effectiveness.

Material efficiency reflects the share of recycled (primary and secondary by-products) residues of production, and therefore the company's commitment to the circular economy's values.

Environmental management systems are estimated as the share of personnel and contractors working at production facilities certified according to international EMS standards such as ISO 14001 or EMAS. The indicator characterizes the degree of responsibility and compliance of the production process with modern requirements.

Among the indicators of social performance, we propose to include the coefficient of the frequency of injuries with a temporary disability, staff training, and wages (Table 2).

Table 2. Indicators of social performance (based on the benchmarking of global industry leaders).

\begin{tabular}{|c|c|}
\hline Indicator & Calculation \\
\hline $\begin{array}{c}\text { The coefficient of the } \\
\text { frequency of injuries with a } \\
\text { temporary disability }\end{array}$ & $\begin{array}{c}\text { Injuries/ } \\
\text { million hours of work }\end{array}$ \\
\hline Employee training & Training days/employee \\
\hline The average salary & $\begin{array}{c}\text { The ratio of labor costs to the } \\
\text { number of staff, thousand } \\
\text { dollars }\end{array}$ \\
\hline
\end{tabular}

Trauma with loss of working time is an incident that prevents a person from returning to work. The rate of injuries with a temporary disability, including deaths, reflects the number of incidents per million person-hours. With the help of the indicator, it is possible to determine the state of working conditions.

Employee training indicator measures the total average number of training days per employee and does not focus on safety and health, but should include it. Training can consist of different development programs: seminars, computer training, self-study, or on-the-job training. Training programs should aim to expand employees' knowledge and skills and help them make the most of their talents.

The average level of wages is calculated by the ratio of labor costs to the number of staff. Characterizes the level of well-being and is a motivating factor for achieving better results.

The proposed indicators of economic performance are (Table 3):

Table 3. Indicators of economic performance (based on the benchmarking of global industry leaders).

\begin{tabular}{|l|l|}
\hline \multicolumn{1}{|c|}{ Indicator } & \multicolumn{1}{c|}{ Calculation } \\
\hline $\begin{array}{l}\text { Investments in new } \\
\text { processes and products }\end{array}$ & $\begin{array}{l}\text { Cost of investment in capital } \\
\text { expenditures and R\&D, \% of } \\
\text { revenue }\end{array}$ \\
\hline Creating added value & $\begin{array}{l}\text { The ratio of gross value added to } \\
\text { revenue, \% }\end{array}$ \\
\hline $\begin{array}{l}\text { Distributed economic } \\
\text { value }\end{array}$ & $\begin{array}{l}\text { value distributed to society (direct } \\
\text { and indirect), \% of revenue }\end{array}$ \\
\hline
\end{tabular}

Investments in new processes and products are the amount of investment in technical and technological innovations and research and development, \% of revenue; reflect the company's commitment to continuous improvement.

The value-added indicator is defined as the ratio of gross value added to revenue, $\%$, and reflects the level of the economic value of the company for the country's economy

Distributed economic value is an indicator of the quantitative assessment of the value sent to society by industry. It includes direct and indirect contributions (taxes, dividends to shareholders, employee salaries, direct payments, etc.)

All these indicators should be evaluated in the process of comparison with the reference global average.

The proposed indicators cover the critical prospects for achieving the best results in the metallurgical industry. Further research aims to model the field of optimal outcomes for domestic enterprises based on benchmarking of global industry leaders and analyze their actual performance, focusing on world leaders' performance.

\subsection{Global benchmarking for monitoring environmental, economic, and social performance}

The study and identification of factors influencing the performance of metallurgical enterprises, in our opinion, 
should be based on empirical global experience of best practices in the industry.

To create an adequate scale and perception of data in the global situation, we have developed a conceptual logic and information model of benchmarking (Fig. 2). According to this model, the basis of comparison is a narrow range of players in the metallurgical market as carriers of "best practices."

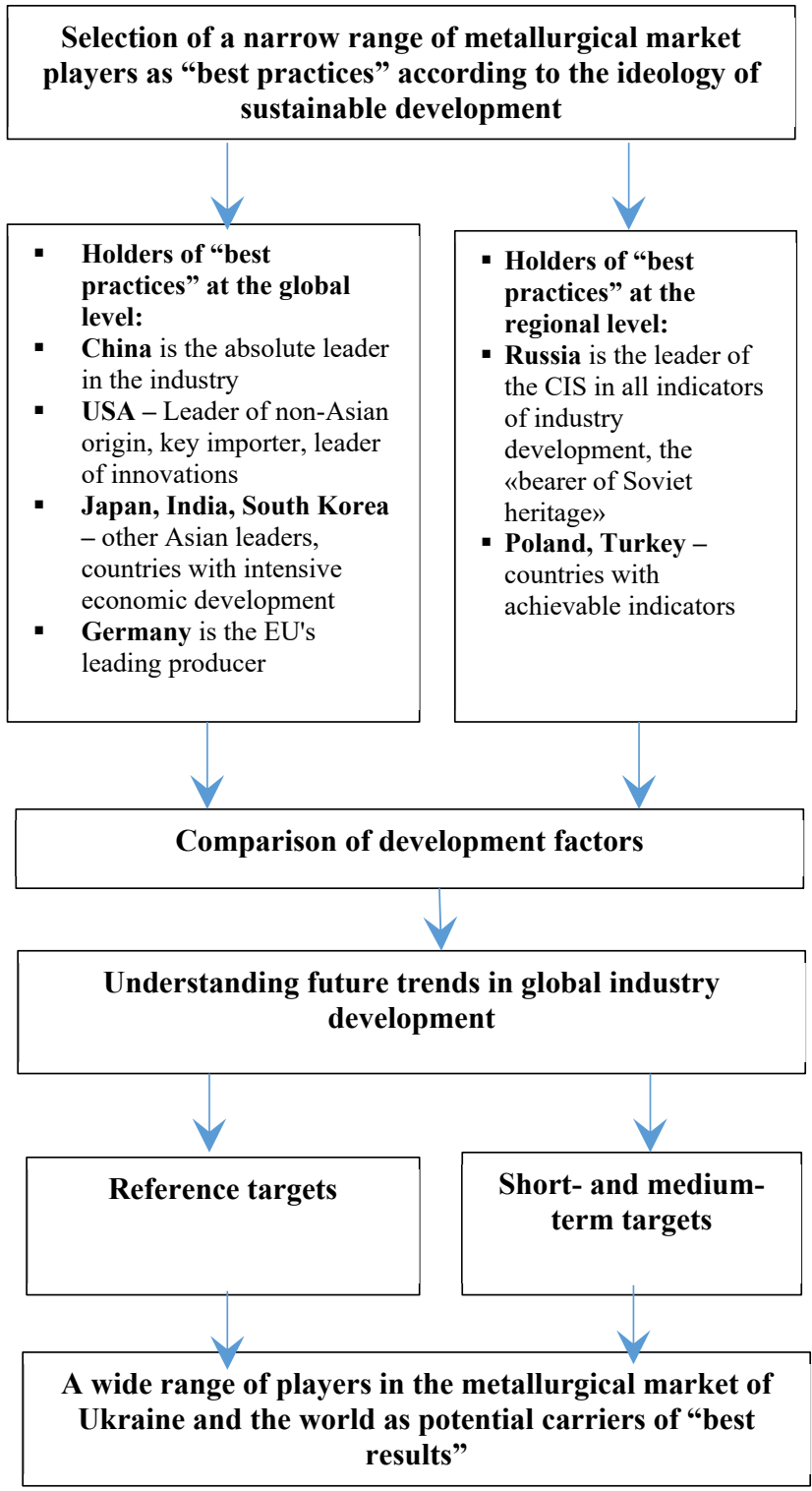

Fig. 2. Logical-information model of benchmarking.

These companies represent China as the most powerful country in the global metallurgical sector, the United States as a leading country of non-Asian origin, and the Russian Federation as a country with identical historical foundations for the industry and the CIS leader.

Also, to understand future trends in global development and Ukraine's place in it, it is necessary to consider a wider range of players.

For this purpose, other Asian leading manufacturers from Japan, India, South Korea, as well as companies from Germany - as a European regional leader, Poland, and Turkey - as countries close to Ukraine's level of economic development.

\section{Research results}

\subsection{Global benchmarking of the steel industry on the ideology of sustainable development and environmental performance}

According to the WSA, the top ten places in the world ranking of steel producers in 2013-2017 are stably occupied by the same companies. The first place is occupied by the multinational corporation "ArcelorMittal SA", whose production facilities are located, including in Ukraine, producing in 201797 million tons of steel (5.86\% of world production), the second - the Chinese China Baowu Group (3.9 \%), the third - the Japanese "Nippon Steel \& Sumitomo Metal Corp" (2.8\%). The twenty largest steel companies (their share in world steel production is $38 \%$ ) include 10 Chinese companies, two metallurgical companies in Japan, India, South Korea, and companies in the United States, Russia, and Brazil. Thus, the development of Chinese metallurgy has a significant impact on the balance of power in metallurgical products' world market. If in the period 1980-2017. world steel production increased 2.4 times - from 716 to 1690 million tons, then in China over the same period, production increased more than 22 times: in 1980, China smelted 37 million tons of steel ( $5 \%$ of world volume), and in $017-$ 831 million tons ( $50 \%$ of world volume). The growth of world steel production in the amount of 974 million tons during this period by $85 \%$ is due to China's formation as the largest player in the world steel market.

The significant acceleration in steel production growth in the last decade has led to a sharp increase in demand for raw materials, particularly iron ore, coal, coke, scrap ferrous metals, and various alloying elements. In our opinion, this, in turn, is a factor in the development of the circular economy.

\section{Environmental requirements as an incentive for innovation}

According to the WSA and the International Energy Agency (IEA), ferrous metallurgy accounts for $6.7 \%$ of the world's total carbon dioxide (CO2) emissions, averaging 1.8 tons of $\mathrm{CO} 2$ per tonne of molten steel. WSA experts note that the reduction of emissions of $\mathrm{CO} 2$ and other harmful substances in the future is possible only through the development and implementation of radically new steelmaking technologies (electric arc furnaces recycling) [7]. Strengthening environmental requirements provokes the introduction of environmental innovations. This is manifested in the use of continuous metal production processes and other innovations in line with the circular economy.

Global trends in the metallurgical industry are the growth of metal production (Fig. 3) against qualitative technological transformations.

An essential ecological innovation of global metallurgical production is the refusal to use the openhearth method of steel production (Fig. 4), which has long occupied a production monopoly, giving way to a more productive oxygen-converter process in the late 1960s. 
The transition from the open-hearth process to the oxygen-converter process saves a significant amount of energy and dramatically reduces the environment's burden. According to the results of 2017, the oxygenconverter method in the world produced $71.4 \%$ of steel, $27.9 \%$ - electric arc, $0.4 \%$ - open-hearth (and this method is used only in the former CIS - up to $6.7 \%$ of production In Ukraine, this figure is much higher $-21.4 \%$.

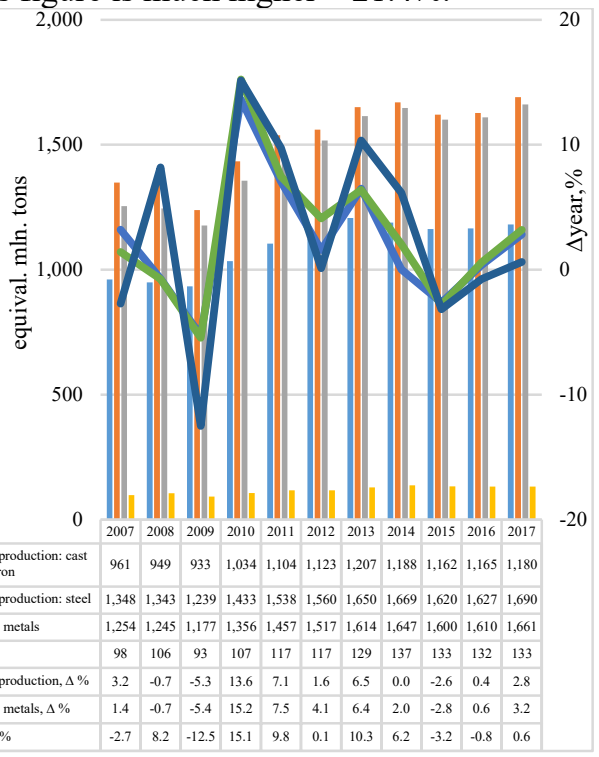

Fig. 3. Global dynamics of metallurgical production, million tons, \% (according to WSA statistics).

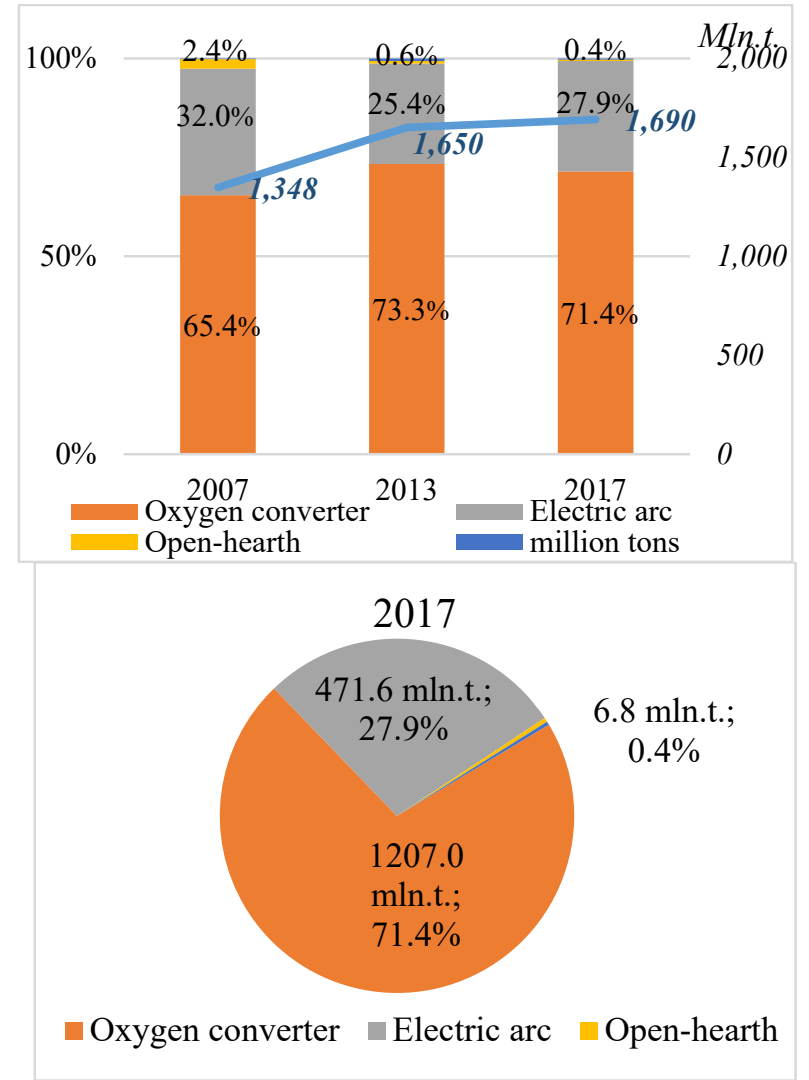

Fig. 4. Metallurgical production by processes, 2007-2017, \% (according to WSA statistics).
Also, the world is intensively developing and implementing the production process of continuous casting, which can also be attributed to the features of the circular economy, covering in 2017 about $96 \%$ of steel produced. In Ukraine, as of 2017, this method produces only $48.8 \%$ of metal products, in Russia $-81.9 \%$, the United States and Turkey $-99.9 \%$, Germany $-95 \%$, India $-85.8 \%$, Italy $-94.8 \%$, China $-98.3 \%$.

\section{Environmental requirements as a source of competitive advantage}

Due to more lenient environmental requirements for production, individual countries gain a competitive advantage that reduces production costs. This leads to a change in the geography of global metallurgy. Director of the IEA N. Tanaka notes that "the introduction of restrictions on carbon emissions in some countries in the absence of similar measures in others threatens unfair competition, can lead to carbon leakage, facilitate the relocation of production to regions with less stringent environmental requirements" [8].

According to the OECD, the metallurgical industry has shifted its major metallurgical industries to Asia, North Africa, and South America in the 21st century [9]. If in 1980, the leading countries in steel production included the USSR ( $21 \%$ of world steelmaking), Japan $(16 \%)$, the United States (14\%), Germany (6\%), China $(5 \%)$, Italy (4\%), France and Poland (3\%) [10], then in the XXI century, according to the WSA, China came in the first place by a huge margin (in 2017 with a figure of 50\% of world steel production). The share of the following 11 producer countries is $43.7 \%$ : EU $(10 \%$, of which $1 / 3$ Germany), Japan and India (6\%), USA (5\%), South Korea and Russia (4\%), Turkey and Brazil (2\%), Italy (1.4\%), Taiwan and Ukraine (1.3\%) (Fig. 5).

China also has a significant share in the production of pig iron (60\%), and the top 10 includes Japan (6.9\%), India (5.42\%), Russia (4.45\%), and South Korea (4\%), Germany $(2.35 \%)$, Brazil $(2.23 \%)$, in eighth place Ukraine $(2.04 \%)$, then - the United States $(1.92 \%)$, and Taiwan (1.28\%). It should be noted that China is a world leader in all metallurgical markets: steel and steel pipe production, the export of metal products, non-ferrous metallurgy markets (nickel, aluminum), while four countries occupy the 2nd-5th places in various markets: Japan, India, Russia, and the United States.

\section{Environmental requirements as a push to eliminate structural crisis phenomena}

Overcoming excess capacity is a necessary condition for more environmentally sustainable conditions for doing business in metallurgy. This will allow the industry to meet long-term challenges better and continue investing in value creation, adapting to the fundamental changes in economic activity caused by the "next production revolution".

Global output growth has led to steel overproduction and under capacity, and the associated imbalance between supply and demand in the global metal market. As of 
January 1, 2018, the world's nominal steel production capacity reached 2,251.2 million tons, with more than $68 \%$ of nominal production capacity concentrated in Asia (of which $46.5 \%$ in China) and $12 \%$ in Europe. $7 \%$ - in North America, 6\% - in the CIS, 7\% - in the rest of the world. The world share of available Ukrainian capacities is about $1.9 \%$ (Fig. 6). According to the results of 2017 , the level of world average capacity utilization does not exceed $75 \%$, leaving more than 600 million tons of excess steelmaking capacity (Fig. 6).

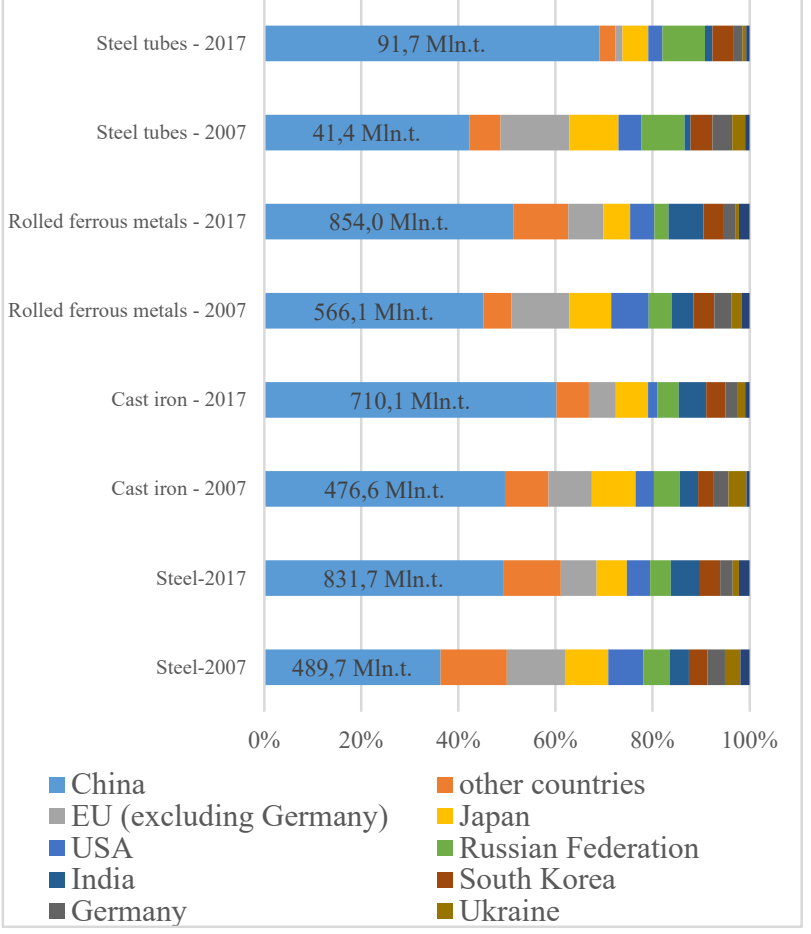

Fig. 5. Production of metallurgical industry products by regions of the world in 2013, 2017 (top countries), \% (according to WSA statistics).

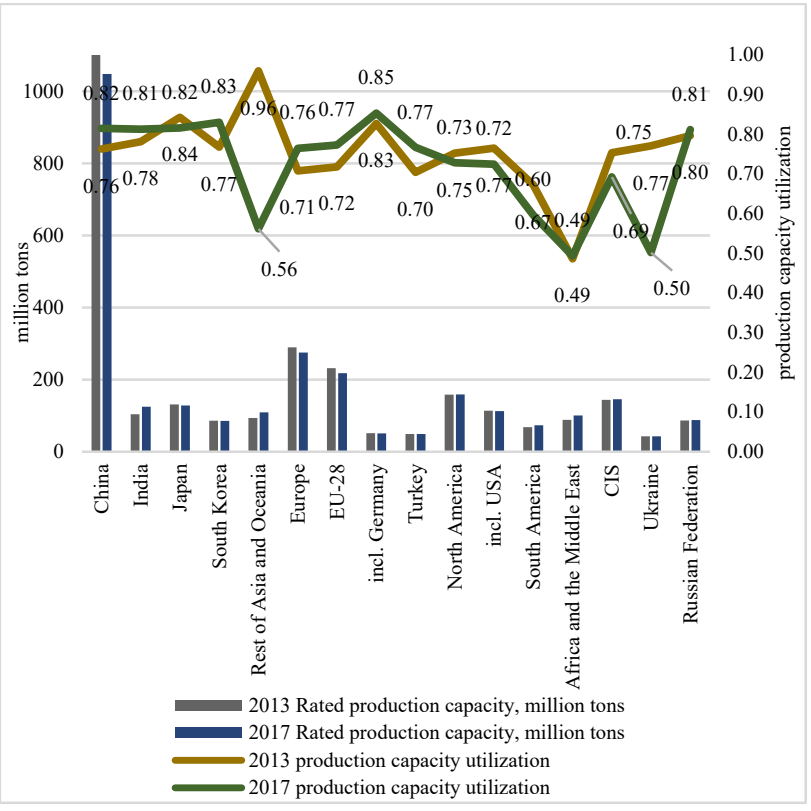

Fig. 6. Use of metallurgical capacity, 2013-2017 (according to [9]).
As shown in Fig. 6, the maximum use of production capacity in the world is only $80 \%$. At the same time, Ukraine is characterized by a much larger excess of production capacity, resulting in a significant part of them $(50 \%)$ is not used. Such data indicate the need to rethink and develop targeted actions to increase the efficiency and effectiveness of the industry's production potential and its optimization. In general, in most regions of the world, there is a positive trend in reducing overcapacity. However, overcapacity continues to be a major concern for the steel industry globally. Their presence affects profitability, creates trade imbalances, creates regional imbalances, and undermines the fight against environmental challenges.

\subsection{Environmental performance of the metallurgical industry in Ukraine}

Metallurgy is one of the strategically important sectors of the economy in Ukraine, providing, in $2017,2.4 \%$ of GDP, $7 \%$ of industrial production, and $19 \%$ of exports. As a consumer of natural monopolies' products and services, the industry used $22 \%$ of electricity, $25.4 \%$ of heat, $6 \%$ of natural gas from the country's total domestic consumption. It accounted for $43 \%$ of rail freight [11].

The main activities in the Ukrainian metallurgical production are the production of cast iron and steel. In current conditions, cast iron, steel, rolled products, ferroalloys, and pipes occupy $25 \%$ of the country's total industrial production (18\% is steel production, $5 \%$ - iron ore production, $2 \%$ - coke production) [12].

Ukraine's metallurgical industry's peculiarities are the large size of production of semi-finished products and the critically small relative share of finished products. $36 \%$ of metallurgical production is the production of cast iron (16.5 million tons in 2018), .39\% - steel (21 million tons), $22 \%$ - rolled products (12.2 million tons), $2 \%$ - steel pipes (1.2 million tons) and only $1 \%$ - other finished products 90.6 million tons). This is one of the reasons for low environmental performance.

Ukrainian ferrous metallurgy structure differs significantly from the structure in developed countries, and this has immediate environmental consequences. Production processes in Ukraine are characterized by technological backwardness: the use of outdated technologies and units, primarily all-open-hearth production process $(21.5 \%$ of the steel in 2017). At the same time, on a global scale, top producers have already completely abandoned it except for the Russian Federation.

According to data for 2018 , in Ukraine only $51.6 \%$ of metal products are manufactured using continuous casting technology. This is the lowest level of use of this technology globally (against $96 \%$ in the world). In total, as of January 1, 2019, the main operating production facilities are in operation: 20 out of 21 blast furnaces, 8 out of 9 open-hearth furnaces, 15 out of 16 converters, 6 out of 15 electric furnaces, and 15 out of 15 continuous casting machines. 


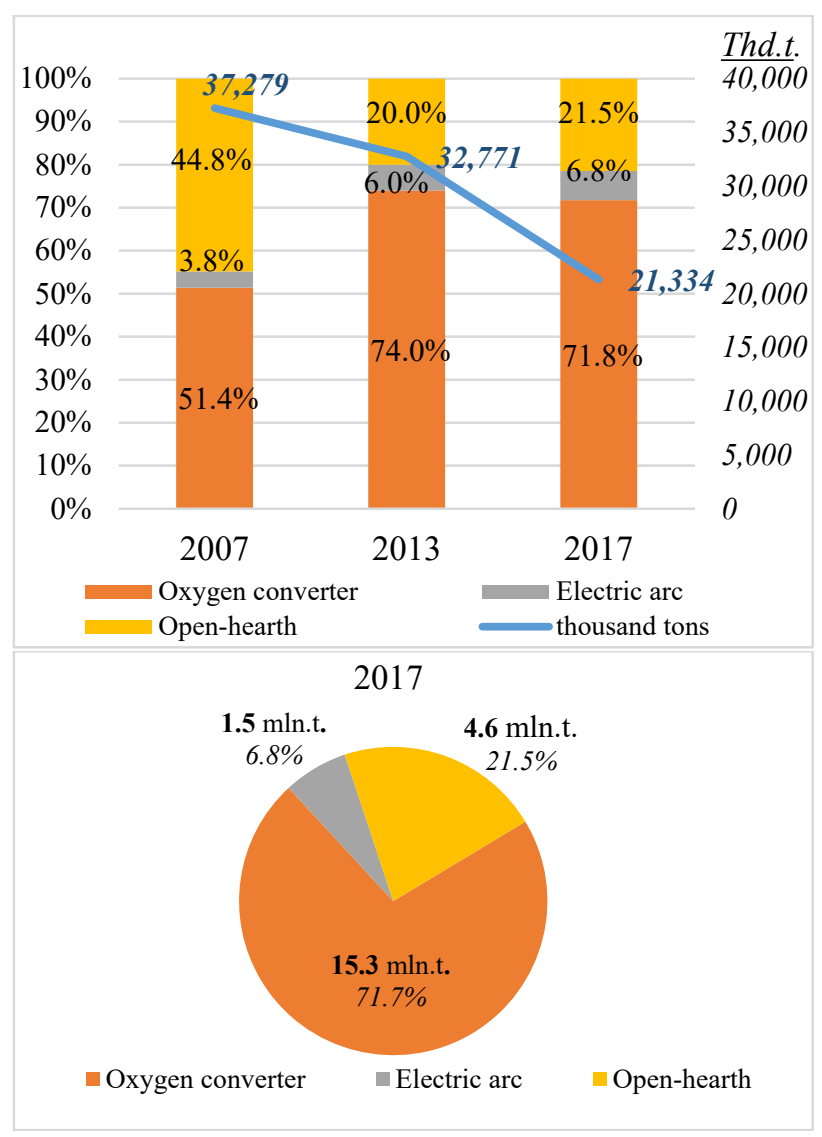

Fig. 7. Steel production by processes in Ukraine (WSA Steel Statistical Yearbook 2009, 2014, 2018).

The technological state of Ukrainian metallurgy is largely explained by the fact that the ferrous metallurgy of Ukraine is the "heir" of this branch of the USSR. In 1990 , it accounted for up to $40 \%$ of the all-Union production of all product groups [13]. The aging of fixed assets in the industry is accompanied by increased costs for fuel and energy and material resources, reduced productivity, deteriorating quality of finished products, large increases in repair costs, and a significant amount of capital investment in the reconstruction and renovation of equipment. Because of technological backwardness, finished metal products of Ukraine are not competitive enough in foreign markets. Ukraine is forced to sell it at discounted prices, which causes anti-dumping lawsuits, because of which Ukraine loses billions of dollars annually. More than $70 \%$ of the industry's output is exported annually. In comparison, about $30 \%$ of domestic consumption of metal products is imported, determining the dependence of the structure and dynamics of production on foreign trade in metal products.

\section{Energy consumption as an ecological problem of metallurgical industry in Ukraine}

The energy consumption of the metallurgical industry is one of the most significant factors influencing its environmental performance. It should be noted that in Ukraine, metallurgy is one of the most energy-intensive industries. Metallurgical production accounts for $52 \%$ of total electricity consumption and $28 \%$ of heat in the processing industry (corresponding shares: $25 \%$ and $24 \%$ of total industrial use, $26 \%$ and $15 \%$ of total use). On average for the year (according to 2018), metallurgists consume about 1840 million cubic meters of natural gas, 11.76 billion $\mathrm{kWh}$ of electricity. The characteristic feature of metallurgical processes is that the most significant part (up to $80-90 \%$ ) of energy resources is spent on processes of own technological needs. The main energy raw material is coal and coke (the share of consumption of this raw material by metallurgy is $93.5 \%$ of the volume consumption by the industry as a whole, and $22 \%$ of the total supply of this type of energy to the Ukrainian market) and natural gas $(60 \%$ and $6 \%$ in 2017, respectively).

The factor of limited resources explains the current trend of increasing the share of expenditures on the energy component due to hostilities in the east of the country and the anti-terrorist operation, as well as the price factor at the global level. Between these two factors, there is a close relationship. Given that the primary raw material for the metallurgical industry is iron ore and coal, which turns into coke in the production process, it is important to understand the trends in the provision of metallurgical enterprises in Ukraine (Fig. 8).

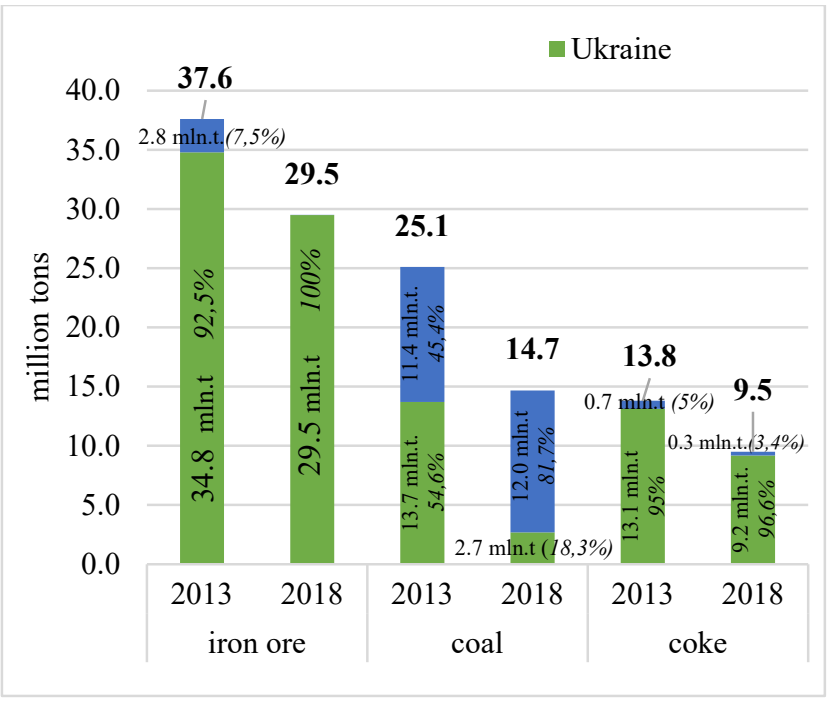

Fig. 8. Provision of metallurgical enterprises of Ukraine with primary raw materials in 2013 and 2018.

This situation with the energy intensity of products dictates the need for a targeted energy-saving policy. Strategic approaches should be associated with the reconstruction of production and the introduction of new energy-saving technological processes. In this regard, some measures that are successfully used in metallurgical enterprises of developed countries should be noted. In Western countries, to reduce the cost of production allows the widespread use of some advanced energy-saving technologies, including the continuous casting of steel (lowers energy costs by $20 \%$ ), dry quenching of coke (in foreign practice, wet quenching of coke). Evaporative cooling of metallurgical units reduces energy costs by two to three times compared to the open cooling scheme [14]. 
According to the Ukrainian Center for Economic and Political Studies named after Razumkov, the greatest reserves for energy efficiency in ferrous metallurgy are cast iron and steel production. We are talking about reducing unit costs by about $25 \%$, or 5 million tons of conventional fuel per year with production volumes at the level of 2013 (for cast iron) and reducing unit costs by about $70 \%$, or 1.5 million tons of conventional fuel per year - on steel.

\subsection{Recommendations for improving environmental performance based on the results of global benchmarking}

The external environment analysis emphasizes the global nature of the industry and the high dependence of performance indicators on the actions of global competitors, who act as leaders and "engines of progress". The lagging position of domestic metallurgy in terms of innovative changes, the reactive nature of achieving competitive advantages in and purely production orientation determine the feasibility of using the strategy of "following the best world practice".

The use of benchmarking research can help realize domestic enterprises' potential and achieve higher economic results by creating and maintaining competitive advantages in the global market. We believe that the results of benchmarking of global industry leaders should be used to apply Ukrainian metallurgical enterprises' targets. The use of benchmarking is in line with the philosophy of Sustainable and Resource Efficient Business Performance Measurement Systems (SuRE BPMS).

For benchmarking of the metallurgical industry, we have selected eight largest world companies (Table 4): ArcelorMittal (Luxembourg), Nucor (USA), POSCO (South Korea), China Baowu Grou (China), Nippon Steel \& Sumitomo Metal Corporation (NSSMC) (Japan), JSC Novolipetsky Metallurgical Plant" (NLMK) (RF), Crown Holdings, Inc. (the USA), Lindab group., Inc. (EU). The proportion of the sample is fully consistent with the scale of enterprises' activities, both globally and nationally.

The selected companies are the leaders in the national context among companies, ahead of almost all industry values indicators. According to the selected companies, the performance indicators described in 2.1 are calculated. Table 5 presents the results of the calculation of environmental performance indicators.

To test the use of benchmarking to improve Ukrainian enterprises' functioning, we formed a sample of 16 largest companies, which provided $88 \%$ of total sales of the metallurgical industry of Ukraine. The first six (Metinvest Holding) (43\%), ArcelorMittal Ukraine (16.2\%), Privat Group (9.2\%), EastOne Group (Interpipe) (7\%), Donbass Industrial Union (ISD) (4.8\%) and DCH-Evraz (3.8\%)) accounted for $84 \%$ of industry-wide sales.

The 16 largest companies accumulate $80 \%$ of assets and $56.6 \%$ of employees in the industry. The results of calculations in terms of environmental performance analysis and possible directions for its improvement are presented in table 6 .
Table 4. A sample of global industry leaders as bearers of "best practices" for achieving environmental performance (based on company data, WSA, CSI).

\begin{tabular}{|c|c|c|}
\hline $\begin{array}{l}\text { Company / } \\
\text { Country }\end{array}$ & Geography of activity & $\begin{array}{c}\text { World share of } \\
\text { crude steel } \\
\text { production.\% }\end{array}$ \\
\hline $\begin{array}{l}\text { ArcelorMittal / } \\
\text { Luxembourg }\end{array}$ & $\begin{array}{l}60 \text { countries (18 of } \\
\text { which have production } \\
\text { facilities, including } 47 \\
\text { integrated plants and } \\
\text { mini-mills) }\end{array}$ & $5.8 \%$ \\
\hline Nucor / USA & $\begin{array}{l}25 \text { scrap processing } \\
\text { mini-mills in North } \\
\text { America, production } \\
\text { facilities in Italy and } \\
\text { Mexico (under } \\
\text { construction) }\end{array}$ & $1.3 \%$ \\
\hline $\begin{array}{l}\text { POSCO / South } \\
\text { Korea }\end{array}$ & $\begin{array}{l}40 \text { Korean subsidiaries, } \\
139 \text { foreign subsidiaries } \\
\text { and } 111 \text { associates and } \\
\text { joint ventures }\end{array}$ & $3.6 \%$ \\
\hline $\begin{array}{l}\text { China Baowu } \\
\text { Group / China }\end{array}$ & $\begin{array}{l}90.7 \% \text { of assets are in } \\
\text { China, the rest }-27 \\
\text { foreign branches and } 8 \\
\text { PJSCs in the regions: } \\
\text { USA, Japan, Germany, } \\
\text { Singapore, Thailand and } \\
\text { Hong Kong. }\end{array}$ & $3.9 \%$ \\
\hline \multicolumn{3}{|c|}{\begin{tabular}{l|l} 
Nippon Steel \& & \\
Sumitomo Metal & \\
Corporation & \\
$($ NSSMC) Group &
\end{tabular}} \\
\hline Japan & $\begin{array}{l}13 \text { metallurgical plants } \\
\text { of Japan + capacities in } \\
15 \text { countries (USA, } \\
\text { Brazil, China, Mexico, } \\
\text { etc.) }\end{array}$ & $2.8 \%$ \\
\hline $\begin{array}{l}\text { PJSC } \\
\text { "Novolipetsk } \\
\text { Metallurgical } \\
\text { Plant" (NLMK) / } \\
\text { RF }\end{array}$ & $\begin{array}{l}20 \text { production sites } \\
\text { located in Russia, USA, } \\
\text { Belgium, Denmark, } \\
\text { Italy, France and India. }\end{array}$ & $1.0 \%$ \\
\hline $\begin{array}{l}\text { Crown Holdings, } \\
\text { Inc. / USA }\end{array}$ & $\begin{array}{l}36 \text { countries (America, } \\
\text { Asia, Europe, Africa): } \\
143 \text { subsidiaries }\end{array}$ & $8.9 \%$ \\
\hline $\begin{array}{l}\text { Lindab group., } \\
\text { Inc. / Sweden, } \\
\text { Germany }\end{array}$ & $\begin{array}{l}32 \text { countries, } 136 \\
\text { branches in the European } \\
\text { market }\end{array}$ & $11,0 \%$ \\
\hline
\end{tabular}

The directions for increasing environmental performance are an investment in resource-saving technologies, production of higher value-added products, investments in energy-saving and new technologies, improvement of management systems, and certification. These recommendations complement ideas for improving environmental performance based on the philosophy of the Concept of Circular Economic and Industry 4.0.

In addition, a tool for improving environmental performance should be a regular environmental audit of production activities and investment projects of Ukrainian enterprises, including for compliance with the ISO 14001: 2015 "Environmental Management System" standard. Based on the audit, complemented by global benchmarking of industry leaders, it is proposed to develop programs to improve environmental performance. An important component of the program should be increasing the level of environmental awareness of staff and stakeholders. This is achieved by publishing the results of environmental audits, developed programs 
on the websites of Ukrainian companies, which is not yet available.

\section{Application of the Concept of Circular Economy to solve environmental problems of metallurgical enterprises}

Metallurgical products are recognized as one of the most circular materials due to their endless processing properties. Broader implementation of the circular economy's principles, such as reduction, reuse, and restoration of production, will have a long-term impact on the metallurgical industry due to its impact on demand in metal-intensive sectors [16].

Price fluctuations for primary resources and finished products, combined with the inability to respond flexibly to changes in demand, increase the need to find ways to improve existing resources' efficiency, develop alternative production technologies based on traditional and universal resources, and resource utilization technologies.

Table 5. Monitoring the environmental performance of world leaders in the industry.

\begin{tabular}{|c|c|c|c|c|c|}
\hline \multirow[b]{2}{*}{ Company } & \multirow[b]{2}{*}{$\begin{array}{l}\text { Result / de- } \\
\text { viation / di- } \\
\text { rection of } \\
\text { correction }\end{array}$} & \multicolumn{4}{|c|}{ Indicator } \\
\hline & & $\begin{array}{c}\text { Green- } \\
\text { house } \\
\text { gas } \\
\text { emissi- } \\
\text { ons }\end{array}$ & $\begin{array}{c}\text { Energy } \\
\text { con- } \\
\text { sumpti- } \\
\text { on }\end{array}$ & $\begin{array}{l}\text { Ma- } \\
\text { terial } \\
\text { effici- } \\
\text { ency }\end{array}$ & \begin{tabular}{|c} 
Envi- \\
ron- \\
mental \\
mana- \\
gement \\
systems
\end{tabular} \\
\hline \multicolumn{2}{|l|}{ Average } & 1,9 & 19,1 & 97,6 & 97,1 \\
\hline \multirow{3}{*}{ ArcelorMittal } & 2019 & 2,1 & 23,8 & 88,6 & 98,1 \\
\hline & ARC*,\% & $-0,9$ & $-0,8$ & 13,3 & 0,1 \\
\hline & $\uparrow \downarrow$ & $\uparrow$ & $\uparrow$ & $\uparrow$ & $\uparrow$ \\
\hline \multirow{3}{*}{ Nucor } & 2019 & 0,9 & 4,9 & 82,0 & 100 \\
\hline & ARC*,\% & 0,0 & $-3,4$ & 2,5 & 0,0 \\
\hline & $\uparrow \downarrow$ & $\uparrow$ & $\uparrow-$ & $\uparrow$ & $\uparrow$ \\
\hline \multirow{3}{*}{ POSCO } & 2019 & 1,9 & 11,5 & 98,4 & 92,3 \\
\hline & ARC $* \%$ & 6,1 & $-0,6$ & 0,0 & 0,3 \\
\hline & $\uparrow \downarrow$ & $\downarrow$ & $\uparrow$ & $\uparrow$ & $\uparrow$ \\
\hline \multirow{3}{*}{$\begin{array}{c}\text { China Baowu } \\
\text { Group }\end{array}$} & 2019 & 1,0 & 17,0 & 99,2 & 92,0 \\
\hline & $\mathrm{ARC}^{*}, \%$ & 0,0 & $-4,0$ & 0,0 & 0,0 \\
\hline & $\uparrow \downarrow$ & $\uparrow$ & $\uparrow$ & $\uparrow$ & $\uparrow$ \\
\hline \multirow{3}{*}{ NSSMC } & 2019 & 2,0 & 23,0 & 99,0 & 96,7 \\
\hline & ARC*,\% & 0,5 & 0,4 & 0,0 & 0,7 \\
\hline & $\uparrow \downarrow$ & $\downarrow$ & $\downarrow$ & $\uparrow$ & $\uparrow$ \\
\hline \multirow{3}{*}{ NLMC } & 2019 & 2,1 & 23,0 & 86,9 & 89,1 \\
\hline & ARC $* \%$ & 0,5 & $-1,8$ & $-7,2$ & 0,2 \\
\hline & $\uparrow \downarrow$ & $\downarrow$ & $\uparrow$ & $\downarrow$ & $\uparrow$ \\
\hline \multirow{3}{*}{$\begin{array}{c}\text { Crown } \\
\text { Holdings, Inc. }\end{array}$} & 2019 & 4,0 & 12,2 & 100 & 99,0 \\
\hline & ARC*,\% & 2,1 & 17,3 & 0,0 & 0,0 \\
\hline & $\uparrow \downarrow$ & $\downarrow$ & $\downarrow$ & $\uparrow$ & $\uparrow$ \\
\hline \multirow{3}{*}{$\begin{array}{l}\text { Lindab } \\
\text { group., inc. }\end{array}$} & 2019 & 7,9 & 1,8 & 89,0 & 97,0 \\
\hline & ARC*,\% & $-13,2$ & $-4,4$ & 0,0 & 0,0 \\
\hline & $\uparrow \downarrow$ & $\uparrow$ & $\uparrow$ & $\downarrow$ & $\downarrow$ \\
\hline
\end{tabular}

* Annual rate of change

In other words, the main trend of metallurgical producers should be the production of products by processing secondary raw materials instead of using mineral resources. Such ideas are an element of the Concept of Circular Economics [17].

Table 6. Benchmarking of environmental performance indicators of world industry leaders and Ukrainian companies.

\begin{tabular}{|l|c|c|c|c|}
\hline Indicator & $\begin{array}{c}\text { Green- } \\
\text { house gas } \\
\text { emissions }\end{array}$ & $\begin{array}{c}\text { Energy con- } \\
\text { sumption }\end{array}$ & $\begin{array}{c}\text { Material } \\
\text { efficien- } \\
\text { cy }\end{array}$ & $\begin{array}{c}\text { Environ- } \\
\text { mental } \\
\text { manage- } \\
\text { ment sys- } \\
\text { tems }\end{array}$ \\
\hline World leaders & 1,9 & 19,1 & 97,6 & 97,1 \\
\hline $\begin{array}{l}\text { Ukrainian } \\
\text { companies }\end{array}$ & 2,2 & 25,3 & 62,7 & $\mathrm{n} / \mathrm{d}$ \\
\hline $\begin{array}{l}\text { Directions of } \\
\text { influence for } \\
\text { environmen- } \\
\text { tal perfor- } \\
\text { mance inc- } \\
\text { rease }\end{array}$ & $\begin{array}{c}\text { Invest- } \\
\text { ments in } \\
\text { resource- } \\
\text { saving } \\
\text { technolo- } \\
\text { gies }\end{array}$ & $\begin{array}{c}\text { Production of } \\
\text { higher value- } \\
\text { added pro- } \\
\text { ducts, } \text { invest- } \\
\text { ments in } \\
\text { energy-saving } \\
\text { and new tech- } \\
\text { nologies }\end{array}$ & $\begin{array}{l}\text { Fol- } \\
\text { lowing } \\
\text { ciples of } \\
\text { circular } \\
\text { economy }\end{array}$ & $\begin{array}{c}\text { Improve- } \\
\text { ment of } \\
\text { manage- } \\
\text { ment sys- } \\
\text { tems and } \\
\text { certi- } \\
\text { fication }\end{array}$ \\
\hline
\end{tabular}

Today in Ukraine, the regulation of the circular economy is still in its infancy. Such regulation is at different stages of development in different regions of the world. The EU Circular Economy Action Plan provides a solid basis for accelerating the transition to a circular economy and sustainable growth. In China, thinking based on a circular economy has been part of legislation and regulations for at least the last ten years. In other regions, such as Brazil, Japan, and Korea, the circular economy's principles are gaining momentum and changing business laws. In general, the transition of a society to a circular economy is only at an early stage. However, this change will likely accelerate in the light of recent trends: the globalization of the economy, changes in government legislation, and innovative business models of the circular economy.

The many advantages of scrap metal as an important steel resource are based on its high-energy efficiency, low carbon emissions, and easy recycling. For the sustainable development of ferrous metallurgy, more attention should be paid to the use of steel scrap in the steel production process. Making full use of scrap metal resources can play a key role in easing pressure on mineral needs. The recycling of steel scrap can significantly reduce iron waste and environmental pollution [18]. The benefits of using scrap metal include the optimization of both energy costs and metal products, demonstrating the ETSAP-TIAM global energy scenario assessment model and the scrap availability assessment model (SAAM).

\section{Application of the Industry 4.0 Concept to increase the environmental performance of metallurgical enterprises}

To increase efficiency, productivity, sustainability, sound process management, and optimal use of resources, Ukrainian metallurgists need to make the most of the Industry 4.0 Concept's capabilities. In this context, the advantages for the metallurgical industry can be such: vertical integration based on Cyber-Physical Production System (CPPS), 100\% traceability of intermediate and 
final products, "Intelligent" product with knowledge of its quality and production history ( one aspect of systems engineering), horizontal integration inside and outside the company, appropriate processing and use of all data, decentralized solutions, self-organization.

Using the Industry 4.0 Concept changes interactions with suppliers and customers using new online platforms, applications, and other systems that offer order tracking and other services. This, in turn, opens up opportunities for entirely new business models and provides for the development of a whole digital "production ecosystem" in which the accumulated data is included in the value chain, helping to maximize the level of environmental performance.

Examining innovations in analytics, mobile solutions, and automation at the global level, we can conclude that the following trends will further contribute to a significant increase in efficiency in the metallurgical industry. First, it is an exponential rise for data available. This leads to a wider implementation of a range of different sensors, including vibration, optics, and sound sensors, reducing storage costs. Second, increasing computing power and developing new analytical methodologies. Traditional statistical methods give way to machine learning methods to simultaneously analyze multiple factors, even if they do not have a linear relationship. Third, mobile technology's deployment to the shop floor contributes to a significant increase in productivity through more efficient field management and process optimization. Fourth, greater automation of support functions combined with data analytics to provide greater flexibility and performance.

\section{Conclusions}

Considering all of the above, we can say that the development of sustainable development ideology has stimulated the emergence of relevant models for Performance Management and Measurement Systems. Such models pay significant attention to environmental problems and approaches to their measurement. Another feature of modern performance assessment models is the use of indicator systems. The use of benchmarking is an instrumental implementation of performance measurement systems since it allows you to set targets for improving performance. We have tested benchmarking to develop the philosophy of tripl sustainable and resourceefficient systems for improving business performance (SuRE BPMS) for development.

With sufficient attention to the formation of indicator systems for management purposes based on the philosophy of sustainable development, sectoral and environmental aspects require further study and implementation. As a global industry, Metallurgy generates its unique opportunities and threats that need to be applied in appropriate performance management models. This article substantiates the need to identify indicators in three areas: for assessing Environmental performance; indicators of Social performance, indicators of Economic performance. To evaluate the environmental performance, we proposed to use such indicators as
Greenhouse gas emissions, Energy consumption, Material efficiency, Environmental management systems.

An analysis of the metallurgical sector's environmental aspects showed that Environmental requirements should be viewed as an incentive for innovation and as a source of competitive advantage. Environmental requirements are also a push to eliminate structural crisis phenomena. Environmental performance efficiency of the metallurgical industry in Ukraine is insufficient, and Energy consumption is the most painful point of metallurgy in Ukraine

To conduct the benchmarking, the article proposes a logical and informational model, the main elements of introducing a high-tech spectrum of metallurgical markets, analysis of tendencies in the global development of metallurgy, the establishment of standard Ukrainian companies, demonstrations of the best practices.

For benchmarking of the metallurgical industry, we have selected eight largest world companies: ArcelorMittal, Nucor, POSCO, China Baowu Grou, Nippon Steel \& Sumitomo Metal Corporation (NSSMC), JSC Novolipetsky Metallurgical Plant “, Crown Holdings Inc., Lindab group. Inc. and compared their results in terms of the proposed environmental performance indicators with the values obtained from the analysis of the activities of 16 Ukrainian companies, which together account for about $90 \%$ of production volumes in Ukraine. Environmental benchmarking of the metallurgical industry made it possible to formulate recommendations for Ukrainian companies.

The scientific novelty of this work lies in the substantiation of a methodological approach to benchmarking tools, adapted taking into account the global nature of the industry and the specifics of environmental problems in it. It should be noted that the implementation of benchmarking in the global industry is somewhat simplified due to the "openness" of worldleading companies, which in general allows collecting the necessary information for analysis. At the same time, it is more efficient to implement the benchmarking information into management practice on an ongoing basis. It is possible to implement it in the context of digital tools, which allows us to maximize the quick presentation of strategic forms of transformation of global solutions the scope of activity of the enterprises.

Promising questions for further research in this direction, in our opinion, are the development of empirical models of target results of the industry; establishment of correlation-regression links between indicators of environmental performance and the variables that determine them (proxy variables); development of management mechanisms that support the introduction of benchmarking research into management practice.

\section{References}

1. M. Bourne et al., Designing, implementing and updating performance measurement systems. International Journal of Operations \& Production Management 20 (2000) 
2. H. Fauzi, G. Svensson, A.A. Rahman, "Triple Bottom Line" as "Sustainable Corporate Performance": A Proposition for the Future. Sustainability 2 (2010)

3. M. O. Pintea, Performance - an evolving concept. University Babes-Bolyai of Cluj-Napoca, http://feaa.central.ucv.ro/annals/v2 2010/0038v2008.pdf/ (2010) Accessed 14 Dec 2020

4. A. Landström et al., A life cycle approach to business performance measurement systems. Procedia Manufacturing 25 (2018)

5. P. Almström et al., Sustainable and resource efficient business performance measurement systems - The handbook (Billes Tryckeri, Mölndal, Sweden, 2017).

6. World Steel Association. https://www.worldsteel.org/ Accessed 14 Dec 2020

7. D. North. Reindustrialization: Reshoring Jobs to the U.S.

http://www.manufacturing.net/blogs/2014/06/reindu strialization-reshoring-jobs-to-the-us/ (2014). Accessed 14 Dec 2020

8. N. Tanaka, New industrial revolution. UNIDO in Russia 1 (2010)

9. OECD Statistics. http://stats.oecd.org/ (2020). Accessed 14 Dec 2020

10. Key information about the global steel industry. Russian steel, http://www.russtal.ru/steel around us/114.html (2013). Accessed 14 Dec 2020

11. Statistical information of State Statistics Service of Ukraine. http://www.ukrstat.org.ua (2020). Accessed 14 Dec 2020.

12. UKRMETALURGPROM, The steel sector in Ukraine: challenges and opportunities. https://www.oecd.org/industry/ind/Item_9_3_Ukrme talurgprom_Ukraine.pdf (2016). Accessed $\overline{1} 4$ Dec 2020.

13. The structure of the ferrous metallurgy industry and development features. http://web.archive.org/web/20200718072135/http:// geolike.ru/page/gl_5304.htm (2020). Accessed 14 Dec 2020

14. A.A. Zlobin, V.N. Kuryatov, A.P. Maltsev, G.A. Romanov, Basic conceptual provisions of energy saving at ferrous metallurgy enterprises. Ecological systems 5 (2005).

15. K.G. Ryabikina, N.I. Ryabikina, A.A. Lisnichenko, Directions of transformation of the business model as a mechanism for ensuring the efficiency of capital management of mining and processing enterprises. Business Inform 1 (2017)

16. V. Bitici, P. Suwingnjo, A.P. Carrie, Quantitative Models for Performance Measurement System. International Journal of Production Economics 64 (2000)

17. Ellen MacArthur Foundation, Towards the circular economy, https://www.ellenmacarthurfoundation.org/assets/do wnloads/publications/Ellen-MacArthur-FoundationTowards-the-Circular-Economy-vol.1.pdf Accessed 14 Dec 2020

18. Y. Xuan, Q. Yue, Retrospective and Prospective Analysis on the Trends of China's Steel Production. Journal of Systems Science and Information 4 (2016) 